\title{
The Outcomes of Cataract Surgery in Small and Normal Pupillary Eyes with Pseudoexfoliation
}

\author{
Psödoeksfoliyasyonu Olan Küçük ve Normal Pupillalı Gözlerde Katarakt Cerrahisi \\ Sonuçlarımız
}

\author{
(D) Mustafa Suat Alıkma1, (D) Sibel Zırtıloğlu², (D) Erkan Ünsal2 \\ 1Servergazi State Hospital, Clinic of Eye, Denizli, Turkey \\ 2istanbul Training and Research Hospital, Clinic of Eye, İstanbul, Turkey
}

\begin{abstract}
Introduction: To evaluate the outcomes of cataract surgery and anterior chamber parameters in pseudoexfoliation cases in our clinic.

Methods: The patients, who were admitted to our clinic between 01.03.2016 and 01.04.2019 and who were found to have cataract and pseudoexfoliation in the examination, were divided into two groups according to dilated pupillary diameter above and below $5 \mathrm{~mm}$ before cataract surgery. Preoperative and postoperative visual acuities, intraocular pressure levels, anterior chamber depths and perioperative posterior capsule opening, development of floppy iris syndrome and corneoscleral suture rates were evaluated.

Results: Sixty eyes of 60 patients, including 31 male (51.7\%) and 29 female (48.3\%) patients, with a mean age of $70.2 \pm 7.1$ (range: 57-82) years, were included. Patients with pupillary diameter above $5 \mathrm{~mm}$ were included in group 1, and those below $5 \mathrm{~mm}$ were included in group 2. Preoperative and postoperative visual acuity according to Snellen chart, intraocular pressure and anterior chamber depths of patients in group 1 were $0.2 \pm 0.1$ (range: $0.1-0.4$ ) vs $0.6 \pm 0.2$ (range: $0.2-1.0$ ), $16.9 \pm 1.7$ (range: $14-20) \mathrm{mmHg}$ vs $15.2 \pm 1.2$ (range: 12-17) $\mathrm{mmHg}$, and $3.04 \pm 0.31$ (range: $2.29-3.73$ ) $\mathrm{mm}$ vs $3.81 \pm 0.38$ (range: $2.48-4.36) \mathrm{mm}$, respectively. Preoperative and postoperative visual acuity according to Snellen chart, intraocular pressure and anterior chamber depths of patients in group 2 were $0.1 \pm 0.1$ (range: $0.1-0.4$ ) vs $0.7 \pm 0.2$ (range: 0.3 1.0), $17.1 \pm 1.5$ (range: $14-20) \mathrm{mmHg}$ vs $16 \pm 1.5$ (range: $12-19$ ) $\mathrm{mmHg}$, and $2.98 \pm 0.44$ (range: $1.98-3.88$ ) $\mathrm{mm}$ vs $3.99 \pm 0.54$ (range: 3.29-5.46) $\mathrm{mm}$, respectively. In group 1, three eyes (10\%) had floppy iris syndrome, four eyes (13.3\%) had posterior capsule rupture, and corneoscleral suture was performed in three eyes (10\%). In group 2, one eye (3.3\%) had floppy iris syndrome, one eye (3.3\%) had posterior capsule rupture and corneoscleral suture was performed in one eye (3.3\%). There was no statistically significant difference between two groups in terms of age, gender, development of floppy iris syndrome, posterior capsule rupture, corneoscleral suturing, preoperative
\end{abstract}

öz

Amaç: Kliniğimizde psödoeksfoliyasyonlu olgulara uygulanan katarakt cerrahisi sonuçlarını ve ön kamara parametre değerlerini değerlendirmektir.

Yöntemler: 01.03.2016 ve 01.04.2019 tarihleri arasında kliniğimize bașvuran, yapılan muayenede katarakt ve psödoeksfoliasyon saptanan olgular katarakt ameliyatı öncesi dilate pupilla çapına göre 5 mm'nin üzerinde ve altında olmak üzere iki gruba ayrıldı. Olguların ameliyat öncesi ve sonrası görme keskinlikleri, göz içi basıncı seviyeleri, ön kamara derinlikleri ile ameliyat esnasında arka kapsül açılması, gevşek iris sendromu gelișimi ve korneaskleral sütür atılması oranları değerlendirilmiştir

Bulgular: Yaş ortalamaları 70,2 $\pm 7,1$ (57-82) olan, 31'i erkek (\%51,7), 29'u kadın (\%48,3) olmak üzere 60 hastanın 60 gözü dahil edildi. Pupilla çapı 5 mm'nin üzerinde olanlar grup 1'e, 5 mm'nin altında olanlar grup 2'ye dahil edildi. Grup 1'deki hastaların ameliyat öncesi ve sonrası Snellen eșeline göre görme keskinliği, göz içi basıncı ve ön kamara derinlikleri sırasıyla $0,2 \pm 0,1(0,1-0,4), 0,6 \pm 0,2(0,2-1,0) ; 16,9 \pm 1,7(14-20)$ $\mathrm{mmHg}, 15,2 \pm 1,2$ (12-17) mmHg; 3,04 $\pm 0,31$ (2,29-3,73) mm, $3,81 \pm 0,38(2,48-4,36) \mathrm{mm}$ olarak tespit edildi. Grup 2'deki hastaların ameliyat öncesi ve sonrası Snellen eșeline göre görme keskinliği, göz içi basıncı ve ön kamara derinlikleri sırasıyla $0,1 \pm 0,1(0,1-0,4), 0,7 \pm 0,2(0,3-1,0) ; 17,1 \pm 1,5$ (14-20) $\mathrm{mmHg}, 16 \pm 1,5$ (12-19) mmHg; 2,97 $\pm 0,44(1,98-3,88) \mathrm{mm}$, 3,99 $\pm 0,54(3,29-5,46) \mathrm{mm}$ olarak tespit edildi. Grup 1'deki 3 (\%10) gözde gevşek iris sendromu, 4 (\%13,3) gözde arka kapsül yırtığı gelișmiş ve 3 (\%10) göze korneaskleral sütür konmuștur. Grup 2'deki $1(\% 3,3)$ gözde gevșek iris sendromu, $1(\% 3,3)$ gözde arka kapsül yırtığı gelişmiş ve $1(\% 3,3)$ göze korneaskleral sütür konmuştur. Her iki grup arasında yaş, cinsiyet, gevşek iris sendromu gelișimi, arka kapsül yırtılması, korneaskleral sütür konulması; ameliyat öncesi ve sonrası görme keskinliği, göz içi basıncı ve ön kamara derinlikleri arasında istatistiksel seviyede anlamlı fark bulunmamıştır (sırasıyla; $p=0,304$, erkek 
and postoperative visual acuity, intraocular pressure and anterior chamber depths $(p=0.304, p=0.508$ for male, $p=0.509$ for female, $p=0.500, p=0.447, p=0.500, p=0.304, p=0.904$, $p=0.644, p=0.025, p=0.437, p=0.150$, respectively).

Conclusion: Pseudoexfoliation is more likely to occur with small pupils. Both conditions involve an increased risk of complications during cataract surgery.

Keywords: Pseudoexfoliation, cataract, small pupil için $p=0,508$, kadın için $p=0,509, p=0,500, p=0,447, p=0,500$, $p=0,304, p=0,904, p=0,644, p=0,025, p=0,437, p=0,150$ ).

Sonuç: Psödoeksfoliyasyonlu olgularda küçük pupilla ile karșılașma ihtimali daha fazladır. Her iki durum katarakt ameliyat esnasında artmış komplikasyon riskini barındırır.

Anahtar Kelimeler: Psödoeksfoliyasyon, katarakt, küçük pupil

\section{Introduction}

Pseudoexfoliation is a gray-white, fibrogranular material that accumulates in the anterior lens surface, pupillary edge, iris and angle in the eye, and in the walls of vessels and tissues in the body (1-3).

An area where pseudoexfoliation accumulates in the eye is the corneal endothelial region. The pseudoexfoliation material deposited in this region causes alterations firstly in the functions of corneal endothelial cells, and changes the shape and number in later periods (4). In addition, pseudoexfoliation material deposited on the surface of the cornea may cause corneal curvature changes in cases with increased intraocular pressure (5). The other accumulation area of exfoliative material in the eye is the anterior chamber angle and lens zonules $(4,6,7)$. The material deposited at the anterior chamber angle can cause resistance to the passage of the aqueous humor to the trabecular network, causing openangle glaucoma (8). Exfoliative material accumulated in the zonules may damage the lens zonules and cause the development of zonular weakness (9). This situation may cause many complications such as loss of zonules, development of aphakia and loss of vitreous in cataract surgery $(10,11)$. In the event that exfoliative material accumulates in the iris, pupillary dilatation occurs less during surgery and an increase in the complications of cataract surgery can be observed $(12,13)$. Another site of pseudoexfoliation in the eye is the lens anterior capsule (14).

The primary accumulation of pseudoexfoliation material outside the eye is the arterial vessel walls. As a result of this accumulation, the probability of cardiovascular and cerebrovascular diseases increases $(15,16)$.

\section{Methods}

Ethics committee approval was obtained from Pamukkale University Faculty of Medicine Medical Ethics Committee (decision no: 05, date: 05.03.2019). The study was conducted in accordance with the Declaration of Helsinki. Written and oral consent was obtained from the patients included in the study and their data were evaluated within the scope of the study.

Patients who presented to our ophthalmology outpatient clinic with low vision complaints between 01.03.2016 and 01.04.2019 and in whom the cause of vision loss was due to cataract were included in our study. Age, gender, preoperative maximum dilated pupillary diameters, preoperative and postoperative visual acuities, anterior chamber depths and intraocular pressures were recorded. Patients with eye disease other than pseudoexfoliation and cataract, patients with zonular dialysis, and patients with previous ocular trauma and surgery were not included in the study.

Anterior chamber depth measurements were performed before and one month after the surgery with the A-Scan ultrasonography under dim light when the pupil was in its natural state. Dilated pupillary measurements of all patients before and one month after the surgery with biomicroscope following 30 minutes after instillation with one drop of tropicamide (Tropamid 1\%, Bilim), cyclopentalate hydrochloride (Cycloplegine 1\%, Abdi Ibrahim) and phenylephrine hydrochloride (Mydfrin 2.5\%, Alcon) at intervals of 10 minutes. Visual acuity and intraocular pressure levels of all patients were measured before and one month after the surgery. Visual acuity level was recorded according to Snellen chart and intraocular pressure level was recorded according to applanation tonometer. All eyes were operated by the same surgeon with experience of over 1000 phacoemulsification surgeries with the same microscope, instruments and surgical instruments. As a surgical method, divide and eat method was used for the nucleus removal in all eyes. In the cases whose posterior capsule integrity was impaired during surgery, vitreous viscoelastic material was removed and the remaining nucleus and cortex were removed by aspiration. In these cases, a 3-part lens was implanted in the sulcus. At the end of the operation, corneoscleral sutures with $10 / 0$ nylon sutures were placed in the patients with posterior capsule opening in the area near the main entrance. The side inlets were inflated with balanced salt solution and the operation was terminated.

Patients were divided into two groups as maximum pupillary dilatation diameter of above or below $5 \mathrm{~mm}$. Preoperative and postoperative anterior chamber depths, visual acuity levels and intraocular pressures and intraoperative complications of the eyes in both groups were recorded.

\section{Statistical Analysis}

Statistical analysis was performed using SPSS 25.00 for Windows (SPSS Inc., Chicago, Illinois, USA) software using a paired t-test. Descriptive statistics were given as numbers and percentages for categorical variables. Pearson tests were performed for normally-distributed variables and Spearman tests were used for non-normally-distributed variables. $\mathrm{P}<0.005$ was considered statistically significant.

\section{Results}

Sixty eyes of 60 patients, including 31 male (51.7\%) and 29 female (48.3\%) patients, with a mean age of $70.2 \pm 7.1$ (range: $57-82$ ) years, were 
included. Nineteen (31.7\%) patients had hypertension. There was no history of diabetes mellitus and alpha-blocker drug use in the patients included in the study. Patients with pupillary diameter above $5 \mathrm{~mm}$ were included in group 1, and those below $5 \mathrm{~mm}$ were included in group 2 . The reference pupillary diameters for grouping were made according to the narrow and normal pupillary width specified in the referenced studies (17-19). Group 1 included 30 eyes of 30 patients, 15 men (50\%) and 15 women (50\%), with a mean age of $69.3 \pm 6.9$ (range: $58-82$ ) years and group 2 included 30 eyes of 30 patients, 16 men (53.3\%) and 14 women (46.7\%), with a mean age of $71.2 \pm 7.2$ (range: $57-79$ ) years. There was no statistically significant difference between two groups in terms of mean age, gender, hypertension, development of floppy iris syndrome, complications, corneoscleral suturing, preoperative and postoperative visual acuity, intraocular pressure and anterior chamber depths ( $p=0.304, p=0.508$ for male, $p=0.509$ for female, $p=0.478, p=0.500$, $p=0.447, p=0.500, p=0.304, p=0.904, p=0.644, p=0.025, p=0.437$, $p=0.150$, respectively) (Table 1 ).

Visual acuity, intraocular pressure and anterior chamber depths were evaluated in both groups before and after surgery. Visual acuity and anterior chamber depth were significantly increased in both groups ( $p=0.000$ and $p=0.000$ for group 1 and $p=0.000$ and $p=0.000$ for group 2 , respectively), and intraocular pressure decreased significantly $(p=0.000$ for group 1 and $p=0.013$ for group 2) (Table 2).

Floppy iris syndrome developed in three eyes (10\%) in group 1 and in one eye (3.3\%) in group 2. Posterior capsule integrity was observed to be impaired in four eyes (13.3\%) in group 1 and in one eye (3.3\%) in group 2. In these five eyes, the nucleus material was not dislocated to the vitreous and the intraocular lens was implanted into the sulcus. Regarding eyes with impaired posterior capsule integrity, corneoscleral sutures were placed in three eyes in group 1 and in one eye in group 2. No statistically significant difference was found between two groups regarding the development of floppy iris syndrome and complications and corneoscleral suturing $(p=0.500, p=0447, p=0.500$, respectively).

\section{Discussion}

Cataract surgery is a necessary method to increase vision in patients with low vision due to cataract $(20,21)$. In pseudoexfoliation cases, cataract causes a decrease in vision and surgical intervention is necessary to increase vision $(22,23)$. Many studies have shown that pupillary dilatation in eyes with pseudoexfoliation is insufficient $(24,25)$. In our study, 30 eyes with preoperative insufficient pupillary dilatation were evaluated. It has also been reported in many studies

\begin{tabular}{|c|c|c|c|}
\hline & Group $1(n=30)$ & Group $2(n=30)$ & $\mathrm{p}$ \\
\hline Age, years (range) & $69.3 \pm 6.9(58-82)$ & $71.2 \pm 7.2(57-79)$ & 0.304 \\
\hline \multicolumn{4}{|l|}{ Gender (\%) } \\
\hline & 15 Male (50\%) & 16 Male (53.3\%) & Male $=0.508$ \\
\hline & 15 Female (50\%) & 14 Female (46.7\%) & Female $=0.509$ \\
\hline Hypertension (\%) & $6(20 \%)$ & $13(43.3 \%)$ & 0.478 \\
\hline Floppy iris syndrome (\%) & $3(10 \%)$ & $1(3.3 \%)$ & 0.500 \\
\hline Posterior capsule rupture (\%) & $4(13.3 \%)$ & $1(3.3 \%)$ & 0.447 \\
\hline Corneoscleral suturing (\%) & $3(10 \%)$ & $1(3.3 \%)$ & 0.500 \\
\hline Preoperative VA (range) & $0.2 \pm 0.1(0.1-0.4)$ & $0.1 \pm 0.1(0.1-0.4)$ & 0.304 \\
\hline Postoperative VA (range) & $0.6 \pm 0.2(0.2-1.0)$ & $0.7 \pm 0.2(0.3-1.0)$ & 0.904 \\
\hline Preoperative IOP, mmHg (range) & $16.9 \pm 1.7(14-20)$ & $17.1 \pm 1.5(14-20)$ & 0.644 \\
\hline Postoperative IOP, mmHg (range) & $15.2 \pm 1.2(12-17)$ & $16 \pm 1.5(12-19)$ & 0.025 \\
\hline Preoperative ACD, mm (range) & $3.04 \pm 0.31(2.29-3.73)$ & $2.97 \pm 0.44(1.98-3.88)$ & 0.437 \\
\hline Postoperative ACD, mm (range) & $3.81 \pm 0.38(2.48-4.36)$ & $3.99 \pm 0.54(3.29-5.46)$ & 0.150 \\
\hline
\end{tabular}

Table 2. Preoperative and postoperative evaluation of eyes in group 1 and group 2 and the results of statistical evaluation of the difference between these values

\begin{tabular}{|l|l|l|l|}
\hline & & Preoperative & Postoperative \\
\hline \multirow{2}{*}{ Group 1 } & VA (range) & $0.2 \pm 0.1(0.1-0.4)$ & $0.6 \pm 0.2(0.2-1.0)$ \\
\hline & IOP, mmHg (range) & $16.9 \pm 1.7(14-20)$ & $15.2 \pm 1.2(12-17)$ \\
\hline ACD, mm (range) & $3.04 \pm 0.31(2.29-3.73)$ & $3.81 \pm 0.38(2.48-4.36)$ \\
\hline Group 2 & VA (range) & $0.1 \pm 0.1(0.1-0.4)$ & $0.7 \pm 0.2(0.3-1.0)$ \\
\hline * $p<0.005$. VA: visual acuity (Snellen chart), IOP: intraocular pressure, ACD: anterior chamber depth & $17.1 \pm 1.5(14-20)$ & 0.000 \\
\hline
\end{tabular}


that the complications that can be observed in cataract surgery may increase in eyes with pseudoexfoliation. The reason for the increase in complications was reported to be insufficient pupillary dilatation and accompanying zonular damage to pseudoexfoliation $(12,26)$. It has also been shown in some studies that the use of capsular tension ring and iris hook during cataract surgery is higher in these eyes than in normal eyes (27-29).

The rate of deterioration of posterior capsule integrity during cataract surgery in the general population was reported as $1.9 \%$ by Chakrabarti and Singh (30), as 0.68 by Chen et al. (31) and as $7.9 \%$ by Zare et al. (32). In our study, posterior capsule integrity was impaired during surgery in five eyes, including four eyes in group 1 and one eye in group 2. Thanigasalam et al. (33) reported that the incidence of posterior capsule rupture in eyes with pseudoexfoliation was 2.833 times higher than normal eyes. The incidence of posterior capsule rupture observed in our study was found to be $8.3 \%$. This result seems to be compatible with the results of other studies. In studies evaluating populations that did not use any medication and had no additional disease, the rate of development of floppy iris syndrome was reported as $0.018 \%$ by Goyal et al. (34) and as $1.18 \%$ by Özer et al. (35). The rate of development of floppy iris syndrome in general populations was stated as $9.09 \%$ by Kaczmarek et al. (36) and as $4.1 \%$ by Neff et al. (37). Tzamalis et al. (38) reported the rate of development of floppy iris syndrome in the general population as $1.29 \%$ in women and $5.17 \%$ in men. In the literature, there is no study on the rate of development of floppy iris syndrome in patients with pseudoexfoliation. In our study, this rate was found to be $6.6 \%$. This rate was found to be higher than that of Goyal et al. (34), Özer et al. (35), Neff et al. (37), and Tzamalis et al. (38)

Increased visual acuity after cataract surgery has been shown in many studies (39-41). In our study, the postoperative visual acuity level was found to be significantly increased compared to the preoperative visual acuity level. Various studies have shown that postoperative intraocular pressure is lower than preoperative values after cataract surgery (4244). In our study, intraocular pressure values measured postoperatively were found to be statistically lower than preoperative intraocular pressure values. Several studies have shown that anterior chamber depth is increased after cataract surgery in eyes with and without pseudoexfoliation (45-48). In our study, anterior chamber depth was increased after cataract surgery similar to other studies.

\section{Conclusion}

There is an increased risk of complications in cataract surgeries in eyes with pseudoexfoliation. Increased surgical risk in cases where pupillary dilatation is insufficient has been shown to increase in many studies, but this risk increase can be reduced by increasing surgical experience.

Ethics Committee Approval: Ethics committee approval was obtained from Pamukkale University Faculty of Medicine Medical Ethics Committee (decision no: 05, date: 05.03.2019).

Informed Consent: Written and oral consent was obtained from the patients included in the study.

Peer-review: Externally peer-reviewed.
Author Contributions: Surgical and Medical Practices - M.S.A.; Concept - M.S.A., E.Ü.; Design - M.S.A.; S.Z.; Data Collection and/or Processing M.S.A.; Analysis and/or Interpretation - M.S.A.; Literature Search - M.S.A.; Writing Manuscript - M.S.A.

Conflict of Interest: No conflict of interest was declared by the authors.

Financial Disclosure: The authors declared that this study received no financial support.

\section{References}

1. Plateroti P, Plateroti AM, Abdolrahimzadeh S, Scuderi G. Pseudoexfoliation syndrome and pseudoexfoliation glaucoma: A review of the literature with updates on surgical management. J Ophthalmol 2015; 2015: 370371.

2. Schlotzer-Schrehardt U, Naumann GO. Ocular and systemic pseudoexfoliation syndrome. Am J Ophthalmol 2006; 141: 921-37.

3. Elhawy E, Kamthan G, Dong CQ, Danias J. Pseudoexfoliation syndrome, a systemic disorder with ocular manifestations. Hum Genomics 2012; 6: 22.

4. Alimligil L, Erda S. Tek taraflı psödoeksfoliasyon sendromlu olgularda kornea endotel ve kalınlık değişiklikleri. Turkiye Klinikleri J Ophthalmol 1995; 4: 52-4.

5. Hepsen IF, YağcI R, Keskin U. Corneal curvature and central corneal thickness in eyes with pseudoexfoliation syndrome. Can J Ophthalmol 2007; 42: 677-80.

6. Dikçi S, Türkoğlu EB, Tök Ö, Burcu A, Örnek F. Sublükse senil katarakt ve psödoeksfolyasyon sendromlu olgularda cerrahi sonuçlarımız. MN Oftalmoloji 2011; 18: 146-52.

7. Iwanejko M, Turno-Krecicka A, Tomczyk-Socha M, Kaczorowski K, Grzybowski A, Misiuk-Hojlo M. Evaluation of the anterior chamber angle in pseudoexfoliation syndrome. Adv Clin Exp Med 2017; 26: 795-801.

8. Desai MA, Lee RK. The medical and surgical management of pseudoexfoliation glaucoma. Int Ophthalmol Clin 2008; 48: 95-113.

9. Ariga M, Nivean M, Utkarsha P. Pseudoexfoliation syndrome. J Curr Glaucoma Pract 2013; 7: 118-20.

10. Sastry PV, Singal AK. Cataract surgery outcome in patients with nonglaucomatous pseudoexfoliation. Rom J Ophthalmol 2017; 61: 196-201.

11. Haripriya A, Ramulu PY, Chandrashekharan S, Venkatesh R, Narendran K, Shekhar M, et al. The aravind pseudoexfoliation study: Surgical and first-year postoperative results in eyes without phacodonesis and nonmiotic pupils. Ophthalmology 2019; 126: 362-71.

12. Fontana L, Coassin M, Iovieno A, Moramarco A, Cimino L. Cataract surgery in patients with pseudoex-foliation syndrome: current updates. Clin Ophthalmol 2017; 11: 1377-83.

13. Brooks AM, Gillies WE. Fluorescein angiography and fluorophotometry of the iris in pseudoexfoliation of the lens capsule. Br J Ophthalmol 1983; 67: 24954.

14. Batur M, Seven E, Tekin S, Yasar T. Anterior lens capsule and iris thicknesses in pseudoexfoliation syndrome. Curr Eye Res 2017; 42: 1445-9.

15. Andrikopoulos GK, Alexopoulos DK, Gartaganis SP. Pseudoexfoliation syndrome and cardiovascular diseases. World J Cardiol 2014; 6: 847-54.

16. Mitchell P, Wang JJ, Smith W. Association of pseudoexfoliation syndrome with increased vascular risk. Am J Ophthalmol 1997; 124: 685-7.

17. Halkiadakis I, Chatziralli I, Drakos E, Katzakis M, Skouriotis S, Patsea E, et al. Causes and management of small pupil in patients with cataract. Oman J Ophthalmol 2017; 10: 220-4.

18. Malyugin B. Cataract surgery in small pupils. Indian J Ophthalmol 2017; 65: 1323-8. 
19. Kim ES, Han SB, Lee SJ, Kim M. Cataract surgery through the small pupil. Clin Interv Aging 2016; 11: 1387-9.

20. Olawoye 00, Ashaye AO, Bekibele CO, Ajayi BGK. Visual outcome after cataract surgery at the university college hospital, ibadan. Ann Ib Postgrad Med 2011; 9: 8-13.

21. Wang W, Yan W, Muller A, He M. A Global view on output and outcomes of cataract surgery with national indices of socioeconomic development. Invest Ophthalmol Vis Sci 2017; 58: 3669-76.

22. Sangal N, Chen TC. Cataract surgery in pseudoexfoliation syndrome. Semin Ophthalmol 2014; 29: 403-8.

23. Turalba A, Cakiner-Egilmez T, Payal AR, Gonzalez-Gonzalez LA, Chomsky AS, Vollman DE, et al. Outcomes after cataract surgery in eyes with pseudoexfoliation: Results from the veterans affairs ophthalmic surgery outcomes data project. Can J Ophthalmol 2017; 52: 61-8.

24. Shastri L, Vasavada A. Phacoemulsification in Indian eyes with pseudoexfoliation syndrome. J Cataract Refract Surg 2001; 27: 1629-37.

25. Hyams M, Mathalone N, Herskovitz M, Hod Y, Israeli D, Geyer O. Intraoperative complications of phacoemulsification in eyes with and without pseudoexfoliation. J Cataract Refract Surg 2005; 31: 1002-5.

26. Tekin K, Inanc M, Elgin U. Monitoring and management of the patient with pseudoexfoliation syndrome: current perspectives. Clin Ophthalmol 2019; 13: 453-64.

27. Psödoeksfoliasyon sendromu ile birlikte olan kataraktların fakoemülsifikasyonu sırasında, kapsüloreksisi takiben kapsül germe halkası uygulaması. Van Tıp Dergisi 2000; 7: 106-12.

28. Tribus C, Alge CS, Haritoglou C, Lackerbauer C, Kampik A, Mueller A, et al. Indications and clinical outcome of capsular tension ring (CTR) implantation: A review of 9528 cataract surgeries. Clin Ophthalmol 2007; 1: 65-9.

29. Belovay GW, Varma DK, Ahmed IIK. Cataract surgery in pseudoexfoliation syndrome. Curr Opin Ophthalmol 2010; 21: 25-34

30. Chakrabarti A, Singh S. Phacoemulsification in eyes with white cataract. Cataract Refract Surg 2000; 26: 1041-7.

31. Chen M, Lamattina KC, Patrianakos T, Dwarakanathan S. Complication rate of posterior capsule rupture with vitreous loss during phacoemulsification at a Hawaiian cataract surgical center: a clinical audit. Clin Ophthalmol 2014; 8: $375-8$

32. Zare M, Javadi M-A, Einollahi B, Baradaran-Rafii A-R, Feizi S, Kiavash V. Risk factors for posterior capsule rupture and vitreous loss during phacoemulsification. J Ophthalmic Vis Res 2009; 4: 208-12.

33. Thanigasalam T, Sahoo S, Kyaw Soe HH. Posterior capsule rupture during phacoemulsification among patients with pseudoexfoliation-is there a correlation? Malays J Med Sci 2014; 21: 51-3.

34. Goyal S, Dalela D, Goyal NK, Chawla S, Dhesi R, Kamboj B, et al. Intraoperative floppy iris syndrome in Indian population: a prospective study on incidence, risk factors, and impact on operative performance. Indian 」 Ophthalmol 2014; 62: 870-5

35. Özer PA, Altıparmak UE, Ünlü N, Hazırolan DÖ, Kasım R, Duman S. Kliniğimizde fakoemülsifikasyon cerrahisinde intraoperatif floppy iris sendromu sıklığı. Glokom-Katarakt 2010; 5.

36. Kaczmarek IA, Prost ME, Wasyluk J. Clinical risk factors associated with intraoperative floppy iris syndrome: a prospective study. Int Ophthalmol 2019; 39: 541-9.

37. Neff KD, Sandoval HP, Fernández de Castro LE, Nowacki AS, Vroman DT, Solomon KD. Factors associated with intraoperative floppy iris syndrome. Ophthalmology 2009; 116: 658-63.

38. Tzamalis A, Matsou A, Dermenoudi M, Brazitikos P, Tsinopoulos I. The role of sex in intraoperative floppy-iris syndrome. J Cataract Refract Surg 2019; 45: 41-47.

39. Farhoudi DB, Behndig A, Mollazadegan K, Montan P, Lundstrom M, Kugelberg M. Spectacle use after routine cataract surgery and vision-related activity limitation. Acta Ophthalmol 2018; 96: 582-5.

40. Toyama T, Ueta T, Yoshitani M, Sakata R, Numaga J. Visual acuity improvement after phacoemulsification cataract surgery in patients aged $\geq 90$ years. BMC Ophthalmol 2018; 18: 280.

41. Sarı ES, Atakan M, Yazıcı A, Ermiș SS. Diyabetik ve diyabetik olmayan gözlerde komplikasyonsuz katarakt cerrahisi sonrası maküla kalınlığındaki değișiminin karșılatırılması. J Kartal TR 2016; 27: 47-51.

42. Lv H, Yang J, Liu Y, Jiang X, Liu Y, Zhang M, et al. Changes of intraocular pressure after cataract surgery in myopic and emmetropic patients. Medicine 2018; 97: e12023-e.

43. İsmi T, Yilmaz A. Effects of cataract surgery on intraocular pressure in patients with and without glaucoma. TJO 2013; 43: 167-72.

44. Iancu R, Corbu C. Intraocular pressure after phacoemulsification in patients with uncontrolled primary open angle glaucoma. J Med Life 2014; 7: 11-6.

45. Gür Güngör S, Akman A, Asena L, Aksoy M, Sarıül Sezenöz A. Changes in anterior chamber depth after phacoemulsification in pseudoexfoliative eyes and their effect on accuracy of intraocular lens power calculation. Turk J Ophthalmol 2016; 46: 255-8.

46. Kim M, Park KH, Kim T-W, Kim DM. Changes in anterior chamber configuration after cataract surgery as measured by anterior segment optical coherence tomography. Korean J Ophthalmol 2011; 25: 77-83.

47. Gür Güngör S, Akman A, Asena L, Aksoy M, Sarýgül Sezenöz A. Changes in anterior chamber depth after phacoemulsification in pseudoexfoliative eyes and effect on accuracy of intraocular lens power calculation. TJ0 2016; 46: 255-8.

48. Huang G, Gonzalez E, Peng P-H, Lee R, Leeungurasatien T, He M, et al. Anterior chamber depth, iridocorneal angle width, and intraocular pressure changes after phacoemulsification: Narrow vs open iridocorneal angles. Arch Ophthalmol 2011; 129: 1283-90. 